\title{
Analyzing the Factors Affecting the Sustainable Municipal Solid Waste Management (MSWM)
}

\author{
Ashwani Kumar1*, Gaurav Dixit' and Dolonchapa Prabhakar ${ }^{2}$ \\ 'Department of Management Studies, Indian Institute of Technology, Roorkee - Haridwar Highway, \\ Roorkee - 247667, Uttarakhand, India; ashwani.983@gmail.com, gauravdixit.fdm@gmail.com \\ ${ }^{2}$ School of Civil Engineering, Lovely Professional University, Jalandhar-Delhi G.T. Road, National Highway 1, \\ Phagwara - 144411, Punjab, India; dolonchapa.prabhakar@lpu.co.in
}

\begin{abstract}
Background/Objective: Providing deeper layout for factors, matters that relate to Municipal Solid Waste Management (MSWM) and to provide analysis about various key factors that play vital role in increasing efficiency of municipal waste management. Methods/Statistical Analysis: The pilot study has been carried out in Punjab region. The analysis has been carried out on the following dependent and independent variables. SPSS software (SPSS 20.0) was used to analyze the data. Finding: Results from the correlation analysis predicted that all variable except Poor collection, transportation and disposal are significant and willing-to-pay has the highest correlation value. Whereas from the multiple regression analysis, it was analyzed that lack of training, awareness, poor collection, transportation and disposal are negatively related with the dependent variable. Applications/Improvements: Study recommends proper collection centers are required for waste collection. Government may more focus on disposal of waste by developing wide range if landfills and maintain the existing landfilling methods. Further efforts of reducing municipal solid waste includes new technological solution of disposal and collection and increases communal responsiveness through more education and awareness on municipal solid waste.
\end{abstract}

Keywords: Correlation, Factors, Municipal Solid Waste (MSW), Municipal Solid Waste Management (MSWM), Multiple Regressions, SPSS

\section{Introduction}

One of the foremost issues faced by the countries worldwide is the MSWM. This prevalently remains constant in the interest of nations that are creating, as the general measure of Metropolitan Strong Waste (MSW) has opened up radically attributable to the quick advance of ventures and heightening populace in the urban ranges. Again, with the availability of restricted resources, fundamental technological treatments and dumping, and poor administration of applicable rules, has created the grave issues of MSWM to persist in countries under development, particularly in relation to recycling and disposal of MSW ${ }^{1}$. Municipal solid waste (MSW) happens to be the most unpredictable strong waste segment, in comparison with more homogeneous waste sectors that result from activities of industries or agriculture. Results shows that due to urbanization, even with a trivial increment in income has resulted in variation of consumption patterns of the inhabitants which as a result has increased the waste types and quantities that has posed bigger challenges for the municipal corporations to cater ${ }^{2}$. For instance, a survey in India exhibited that an increase in population of $49 \%$ has resulted in $67 \%$ growth for MSW in the same duration. The expanding volumes of waste being produced would not be an issue if waste was seen as an asset and oversaw legitimately ${ }^{3}$.

\section{Literature Review}

Being the greatest creating nation on the globe, China needs specific consideration. According to the accessible information, China has brought forth 190 million metric huge amounts of MSW in the year 2004 and turned into the world's greatest MSW producer4. Looking into the

${ }^{*}$ Author for correspondence 
scenario, China has dedicated significant attempt in managing its MSW. From the years 1990-2004, venture in MSW treatment infrastructure and equipment has hiked to twenty-one times, and above thirty times more MSW is presently disposed off safely or treated ${ }^{5}$. Nevertheless, the safe discarding of MSW was highly restricted in 1990 and the rate of safe disposal reached up to $53 \%$ in 2006, hence the numerous challenges of safe disposal of MSW still persists. Numerous outlines have been recorded to deliberate the position of and the challenges faced by MSW in China ${ }^{6^{6}}$ ${ }^{7}$. To a great extent, arrive employments of civil strong waste era potential are business, mechanical, institutional, private and agrarian land uses, and development and annihilation handle. A review led as of late, expressed that in the midst of the effects of private land utilizes the most extreme weight is on the strong waste era aspect ${ }^{8}$. In the previous few eras, improvement and advance in MSWM delay with the sanctioning of a crisp arrangement of laws and approaches. For example, the law on Circular Economy Promotion that is as a result from 2009 is perceived a legitimate skeleton on waste decrease, reuse and recycling 9 . Administration Measures on Urban Waste, issued in 2007, additionally overstated the ensuing standards for MSWM: peril lessening (verifying that no perilous mixes are discharged into the earth), volume diminishment, asset recuperation (moving profitable squanders into option assets), and maker responsibility ${ }^{10}$. The technique for "ecological insurance display urban areas" and "eco-urban areas" has particularly set harder models for safe transfer of MSW at the rates of $85 \%$ and $90 \%$ respectively ${ }^{11}$. The Cities that aim at accomplishing these labels for the most part include squander minimization and safe transfer in their way of action ${ }^{12}$. The Model urban areas ought to set an occasion of accomplishment to different urban areas that attempt to improve their MSWM practices. The extra noteworthy approaches that can likewise be instilled are those worried to charges for waste treatment and appropriations for electric power made from waste start which were distributed in 2002 and 2006, separately would help in MSWM ${ }^{\frac{13}{3}}$. Taking into record these advances, it is imperative to assess the current state of MSWM and perceive the hindrances and in addition prospects for MSWM in China. Discussing Solid waste administration it is watched that it is a multi-dimensional issue. When all is said in done, Municipalities look for hardware as a pathway to get an answer for the assortment of issues they counter. This review specifically highlights that a productive framework depends on innovative arrangements as well as legitimate, natural, institutional, socio social and monetary linkages that must be there to encourage the general framework to function ${ }^{14}$.

\section{Factors Affecting MSW}

\subsection{Lack of Legal Policies and Strategies}

Contractual workers that are approved to gather client installments, have no legal influence on the general population and bureaucratic systems of the law, against defaulters make the procedure considerably more costly, unwieldly and muddled instances of non-installment are not rare because of frail requirement components and deficient support got from nearby government on upgrading the installment of client installment. Related perceptions were made that expressed that Kinondoni district by-laws are ineffectively forced and settings of laws are for the most part weak, which give space to unlawful strong waste administration rehearses and non-installment of client charges ${ }^{15}$.

\subsection{Willing Ability to-Pay for Waste Administration}

Willingness-to-pay (WTP) for waste administration offices or administrations is exceptionally integral for the achievement of the private segment's support in the city strong waste administration program. The slant to pay or not to pay could have coordinate effect on the productivity and viability of civil strong waste administration WTP for waste management ${ }^{\frac{16}{}}$. Most of the analysis shows improved solid waste management by household's willing to pay for services ${ }^{16}$. Some research pointed out that older people are not willing to pay because lots of people consider collection of municipal solid waste is not our duty and consider it is government responsibility and we are not at risk to pay for the waste accumulation administrations. Opposite side youth may be more acquainted with cost sharing and all the more eager to pay for gathering administrations.

\subsection{Attitude and Perception towards Waste Management}

Attitude has been found to be an important predictor in explaining intention or behavior towards solid waste management and the relationship are significant. Attitude may be positively influenced through awareness camps and program and giving education about the negative aspects of inadequate collection of waste with regard to public health policies and environmental conditions $\mathbf{s}^{17}$. Perception is the primary process by which human beings obtain knowledge 
of the world. It involves the actions of our sense organs (sight, hearing, touch, taste and smell) in responding to external stimulation ${ }^{18}$. Perceptions are influenced by our habits and perceived knowledge, resources, and beliefs but can be created without experience and knowledge of the person ${ }^{19}$.

\subsection{Lack of Training and Awareness Program}

Lack of group mindfulness with respect to the benefits of waste reusing by treating the soil was additionally reported in Iringa Municipality in Tanzania ${ }^{20}$. The waste manager includes municipal councilors, municipal staff and other private agencies/person involved in transportation, collection, storage and processing of waste. With the help of government, the thrust of the awareness program and campaign was on facilitating a Door To Door Collection (DTDC) of segregated waste.

\subsection{Absence of Resource Reusing and Source Partition of Squanders}

Re-utilize, reusing, and recovery of squanders comprise of revamp, change and re-fabricate of material, items and parts which adds noteworthiness to the item, minimizes wastes ${ }^{21}$, makes work and creates pay. In a related review, reported that KIWODET, a group based association that works in Kinondoni district in Dar es Salaam, slighted push to execute elective waste administration practices, for example, reusing, re-utilize, or treating the soil, since no motivators were accessible to move such naturally agreeable strong waste administration practices.

\subsection{Poor Collection, Transportation and Disposal}

Collection ratio of MSW varies from place to place and the methods that are available are either insufficient or ineffective. Majorly the collection systems vary from the use of small and poor quality of metal or plastic containers or enclosures and waste platforms to well monitored bins, which are disgustingly insufficient. The transportation systems comprise of a great diversity of vehicles. If more proficient collection trucks are operated then the problem is that the fleet in common is old and their availability is less. This affects the entire collection method, as up to $50 \%$ of the trucks may not be in operational condition due to unavailability of spare parts or continuous collapse. Supply of storage bins may be in short or collection is not appropriate, as a result it may result to spilling and littering about of MSW. For the accumulation and handling of waste for organized disposal, there are scarcely any transfer stations. Due to lack of technical proficiency that is able to instruct the MSW collection and transfer systems, the crucial problem emerges. In developing countries, municipal solid waste is usually disposed of by transporting and dumping in open spaces, which are directly dangerous to environment. In major of the municipality systems, collection of waste is in unmanned and unmonitored landfills with no attention towards its discharge to environment. In the process of waste treatment, the major sources of release are leachate and airborne releases from landfills and further treatment procedure such as incineration and compositing as well as transportation of waste. It is vital that the containers to be used needs to be operational to the type of materials and the collection vehicles used. It is also necessary that the containers must also be durable, economical, easy to handle, as well as corrosion resistant, unaffected by different weather conditions, etc. Usually thick plastics are used for their construction. In case of mechanized collection system, specially designed containers are used which fit the truck mounted loading mechanisms. The environmental effect of leachate depends on the quantity discharged and on the concentration of substances in it. The discharge of leachate was anticipated on the basis of real landfill area during the entire life span of each landfill and compositing site $^{22}$. The most desirable disposal of solid waste is landfilling. There are other types of landfills, open landfills and sanitary landfills. Open landfills the common used landfilling method for all developing countries. For final disposal of MSW, Sanitary landfilling is a suitable and suggested method. It is an essential part of MSWM, since all other options generate some residue that must be disposed off through landfilling. Nevertheless, it seems that landfilling will remain to be the most extensively adopted practice in India in the near future, during which certain improvements needs to be made to ensure the sanitary landfilling.

\section{Research Methodology}

The pilot study has been carried out in Punjab region in the process of successful MSWM initiative. Designing the methodology after the peer review of literature.

1. Identify dependent and independent variable.

2. Construct a questionnaire.

3. Reliability check of questionnaire using Cronbach's Alpha. 
4. Collection of data and analyze the important finding.

5. Draw results and conclusion

\subsection{Statistical Tools}

Using SPSS software (SPSS 20.0) for analysis of data is discussed. Further using tools like correlation and multiple regressions for setting the relationship between the factors and variables and to finalize the results.

\subsection{Hypotheses were assumed}

1. $\mathrm{H}_{1}$ Lack of legal Policies and Strategy affects the MSWM.

2. $\mathrm{H}_{2} \mathrm{WTP}$ affects the MSWM.
Table 1. Cronbach's alpha test

\begin{tabular}{|c|c|}
\hline Factors & Cronbach's Alpha \\
\hline $\begin{array}{c}\text { Factor 1 Lack of legal Policies and } \\
\text { Strategy }\end{array}$ & .719 \\
\hline Factor 2 WTP for waste management & .721 \\
\hline $\begin{array}{c}\text { Factor 3 Attitude and Perception } \\
\text { towards waste management }\end{array}$ & .780 \\
\hline Factor 4 Lack of training and awareness & .725 \\
\hline $\begin{array}{c}\text { Factor 5 Poor collection transportation } \\
\text { and disposal }\end{array}$ & .765 \\
\hline $\begin{array}{c}\text { Factor 6 Lack of Resource recycling and } \\
\text { source separation of wastes }\end{array}$ & .730 \\
\hline Factor 7 Successful MSWM & .755 \\
\hline
\end{tabular}

Table 2. Correlation analysis of input factors with output factor

\begin{tabular}{|c|c|c|c|c|c|c|c|c|}
\hline \multicolumn{9}{|c|}{ Correlations Analysis } \\
\hline & & $\begin{array}{c}\text { Lack of legal } \\
\text { Policies and } \\
\text { Strategy }\end{array}$ & WTP & $\begin{array}{c}\text { Attitude } \\
\text { and } \\
\text { Perception }\end{array}$ & $\begin{array}{c}\text { Lack of } \\
\text { training } \\
\text { and } \\
\text { awareness }\end{array}$ & \begin{tabular}{|c} 
Poor \\
collection \\
transportation \\
and disposal
\end{tabular} & $\begin{array}{c}\text { Lack of } \\
\text { Resource } \\
\text { recycling } \\
\text { and source } \\
\text { separation of } \\
\text { wastes }\end{array}$ & $\begin{array}{c}\text { Successful } \\
\text { MSWM }\end{array}$ \\
\hline $\begin{array}{c}\text { Lack of legal Policies } \\
\text { and Strategy }\end{array}$ & $\begin{array}{c}\text { Pearson } \\
\text { Correlation } \\
(\mathrm{r})\end{array}$ & 1 & $.469^{*}$ & .301 & .172 & .090 & .200 & $.549^{*}$ \\
\hline WTP & $\begin{array}{c}\text { Pearson } \\
\text { Correlation } \\
(\mathrm{r}) \\
\end{array}$ & $.469^{*}$ & 1 & .378 & .276 & .124 & .376 & $.655^{* *}$ \\
\hline $\begin{array}{l}\text { Attitude and } \\
\text { Perception }\end{array}$ & $\begin{array}{c}\text { Pearson } \\
\text { Correlation } \\
(\mathrm{r}) \\
\end{array}$ & .301 & .378 & 1 & .303 & -.252 & -.085 & $.535^{* *}$ \\
\hline $\begin{array}{c}\text { Lack of training and } \\
\text { awareness }\end{array}$ & $\begin{array}{c}\text { Pearson } \\
\text { Correlation } \\
(\mathrm{r}) \\
\end{array}$ & .172 & .276 & .303 & 1 & .156 & $.512^{*}$ & $.458^{*}$ \\
\hline $\begin{array}{c}\text { Poor collection } \\
\text { transportation and } \\
\text { disposal }\end{array}$ & $\begin{array}{c}\text { Pearson } \\
\text { Correlation } \\
(\mathrm{r}) \\
\end{array}$ & .090 & .124 & -.252 & .156 & 1 & $.571^{* *}$ & .100 \\
\hline $\begin{array}{l}\text { Lack of Resource } \\
\text { recycling and source } \\
\text { separation of wastes }\end{array}$ & $\begin{array}{c}\text { Pearson } \\
\text { Correlation } \\
\text { (r) }\end{array}$ & .200 & .376 & -.085 & $.512^{*}$ & $.571^{* *}$ & 1 & $.536^{*}$ \\
\hline Successful MSWM & $\begin{array}{c}\text { Pearson } \\
\text { Correlation } \\
(\mathrm{r})\end{array}$ & $.549^{*}$ & $.655^{* *}$ & $.535^{* *}$ & $.458^{*}$ & .100 & $.536^{*}$ & 1 \\
\hline \multicolumn{4}{|c|}{ *. Correlation is significant at the 0.05 level (2-tailed). } & \multicolumn{5}{|c|}{ **. Correlation is significant at the 0.01 level (2-tailed). } \\
\hline
\end{tabular}


3. $\mathrm{H}_{3}$ Attitude and Perception towards waste management affects the MSWM.

4. $\mathrm{H}_{4}$ Lack of training and awareness programme affects the MSWM.

5. $\mathrm{H}_{5}$ Lack of Resource recycling and source separation of wastes affects the MSWM.

6. $\mathrm{H}_{6}$ Poor collection transportation and disposal affects the MSWM.

\section{Results and Discussions}

Reliability Analysis of Questionnaire was done from suggestion received from experts from local individuals, municipal councilors and responsible officials from regional municipal department. After obtaining feedback from the panel of experts, Cronbach's Alpha analysis was utilized to check the authenticity of factors. Table 1 displays the reliability and validity of factors.

From the Correlation Analysis, we analyze:

1. Input factor 1 Lack of legal Policies and Strategy significantly correlates $\left(r=.549^{*}\right)$ with output factor MSWM. $\mathrm{H}_{1}$ is accepted and hence it is concluded that Lack of legal Policies and Strategy significantly affects the successful MSWM.

2. Input factor 2 (WTP significantly correlates $\left(\mathrm{r}=.655^{* *}\right)$ with output factor MSWM. $\mathrm{H}_{2}$ is accepted and hence it is concluded that WTP significantly affects the successful MSWM.

3. Input factor 3 Attitude and Perception towards waste management significantly correlates $\left(\mathrm{r}=.535^{* *}\right)$ with output factor MSWM. $\mathrm{H}_{3}$ is accepted.

4. Input factor 4 Lack of awareness and training significantly correlates $\left(r=.458^{*}\right)$ with output factor MSWM. $\mathrm{H}_{4}$ is accepted.

5. Input factor 5 Poor collection transportation and disposal not significantly corzrelates $(\mathrm{r}=.100)$ with output factor MSWM. $\mathrm{H}_{5}$ is rejected and hence it is concluded that Poor collection transportation and disposal does not significantly affects the MSWM due to lack of technology aspects regarding transportation and collection in Punjab. Therefore, correlation between Poor collection transportation and disposal and MSWM is too weak.

6. Input factor 6 Lack of Resource recycling and source separation of wastes significantly correlates $\left(\mathrm{r}=.536^{*}\right)$ with output factor MSWM. $\mathrm{H}_{6}$ is accepted
Results from the correlation analysis, predicted that all variable except Poor collection transportation and disposal are significant and willing-to-pay has the highest correlation value of 0.655 . Table 2 displays the correlation analysis of independent variable and dependent variable.

From the multiple regression analysis, we breakdown:

From the model rundown, the Adjusted R Square value lets us know that our model records for $47.1 \%$ of variety in the reliant variable. Table 3 shows multiple regression analysis of combined independent variables with dependent

\section{Standardized Beta Coefficient ( $\beta$ ):}

1. Beta value $(\beta=0.213)$, which demonstrates the relapse coefficient, gives level of relationship between Lack of lawful Policies and Strategy and MSWM.

2. Beta value $(\beta=0.168)$ which demonstrates the relapse coefficient, gives level of relationship between WTP and MSWM.

3. Beta value $(\beta=0.467)$ which shows the relapse coefficient, gives level of relationship amongst Attitude and Perception and MSWM.

4. Beta value $(\beta=0.435)$ which shows the relapse coefficient, gives level of relationship between Lack of Resource reusing and source division of squanders and MSWM. Table 4 shows the institutionalized beta coefficients

From the coefficient table, the institutionalized beta coefficients give a measure of the commitment of every variable to the model.

From the multiple regression analysis, we analyze Lack of training and awareness and Poor collection transportation and disposal are negative related with the dependent variable.

Table 3. Multiple regression analysis of combined input variables with output variable

\begin{tabular}{|c|c|c|c|c|}
\hline \multicolumn{5}{|c|}{ Model summary } \\
\hline Model & $\mathrm{R}$ & $\begin{array}{c}\mathrm{R} \\
\text { Square }\end{array}$ & $\begin{array}{c}\text { Adjusted R } \\
\text { Square }\end{array}$ & $\begin{array}{c}\text { Std. Error of the } \\
\text { Estimate }\end{array}$ \\
\hline & & & & \\
\hline 1 & $.781^{\mathrm{a}}$ & .686 & .471 & .4795 \\
\hline
\end{tabular}

a. Predictors: (Constant), Lack of Resource recycling, Lack of legal Policies and Strategy, Attitude and Perception, Poor collection transportation and disposal, Willing-to-pay, Lack of awareness and training. 
Table 4. The standardized beta coefficients ${ }^{\mathrm{a}}$

\begin{tabular}{|c|c|c|c|c|c|}
\hline & \multicolumn{2}{|c|}{ Unstandardized Coefficients } & \multirow{2}{*}{$\begin{array}{c}\begin{array}{c}\text { Standardized } \\
\text { Coefficients }\end{array} \\
\text { Beta }(\beta) \\
\end{array}$} & \multirow{2}{*}{$\mathrm{T}$} & \multirow{2}{*}{ Sig.(p) } \\
\hline & $\mathrm{B}$ & Std. Error & & & \\
\hline (Constant) & -.840 & .690 & & -1.217 & .240 \\
\hline Lack of legal Policies and Strategy & .219 & .175 & .213 & 1.249 & .229 \\
\hline WTP & .208 & .238 & .168 & .875 & .394 \\
\hline Attitude and Perception & .559 & .223 & .467 & 2.506 & .023 \\
\hline Lack of training and awareness & -.080 & .274 & -.056 & -.292 & .774 \\
\hline Poor collection transportation and disposal & -.076 & .232 & -.062 & -.328 & .747 \\
\hline $\begin{array}{l}\text { Lack of Resource recycling and source separation of } \\
\text { wastes }\end{array}$ & .587 & .311 & .435 & 1.888 & .076 \\
\hline
\end{tabular}

a. Dependent Variable: MSWM.

\section{Conclusion}

City strong waste is a quickest developing waste, at first showed up in created nations and now stretches out to other creating nations. Pilot study was accomplished for a constrained example measure keeping in mind the end goal to learn the variables influencing the supportable city strong waste administration (MSWM). The study was additionally detailed to delineate MSWM issues in Punjab locale, which would audit the current practices in MSWM, both vertically with legislative association, scholastic research organizations, and evenly among systems who manages strong waste. The reactions illuminated at the dynamic level the complexities in the feasible MSWM prepare and additionally encouraged a characteristic investigation of the variables influencing MSWM. Ponder prescribes appropriate gathering focuses are required for waste accumulation and process them. Government may more concentrate on transfer of waste by growing wide range if landfills and keep up the current landfilling techniques .Further efforts of reducing municipal solid waste includes new technological solution of disposal and collection, and increases communal responsiveness through more education and awareness on municipal solid waste.

\section{References}

1. Attallah OS, Senouci A, Kandil A, Derham HA. Utilization of life-cycle analysis to evaluate sustainability rating systems for construction projects with a case study on Qatar Sustainability Assessment System (QSAS). Smart and Sustainable Built Environment. 2013; 2(3):272-87.
2. India: State of the Environment, United Nations Environment Programme. The Energy and Resources Institute; 2001. p. 133-49.

3. Pokhrel D, Viraraghavan T. MSWM in Nepal: practices and challenges. Waste Management. 2005 Dec 31; 25(5):555-62.

4. Zhang DQ, Tan SK, Gersberg RM. MSWM in China: status, problems and challenges. Journal of Environmental Management. 2010 Aug; 91(8):1623-33.

5. Zhang KM, Wen ZG. Review and challenges of policies of environmental protection and sustainable development in China. Journal of Environmental Management. 2008 Sep 30; 88(4):1249-61.

6. Jiang Y, Kang MY, Liu Z, Zhou YF. Urban garbage disposal and management in China. Journal of Environmental Sciences. 2003 Jan; 15(4):531-40.

7. Wang $\mathrm{H}$, Nie Y. Municipal solid waste characteristics and management in China. Journal of the Air and Waste Management Association. 2001 Feb; 51(2):250-63.

8. Chithra K, Anilkumar PP, Naseer MA. Quantification of residential land use characteristics from an impact generation potential perspective. Indian Journal of Science and Technology. 2015 Oct; 8(28):1-7.

9. Chen X, Geng Y, Fujita T. An overview of MSWM in China. Waste Management. 2010 Apr; 30(4):716-24.

10. Management Measure on Urban Waste [Internet]. 2016 [cited 2016 Mar 23]. Available from: http://www.gov.cn/ ziliao/flfg/2007-06/05/content_636413.html.

11. Zheng L, Song J, Li C, Gao Y, Geng P, Qu B, Lin L. Preferential policies promote Municipal Solid Waste (MSW) to energy in China: current status and prospects. Renewable and Sustainable Energy Reviews. 2014 Aug 3; 36:135-48.

12. Geng Y, Zhu Q, Doberstein B, Fujita T. Implementing China's circular economy concept at the regional level: A review of progress in Dalian, China. Waste Management. 2009 Feb; 29(2):996-1002. 
13. Tian H, Gao J, Hao J, Lu L, Zhu C, Qiu P. Atmospheric pollution problems and control proposals associated with solid waste management in China: a review. Journal of Hazardous Materials. 2013 May; 252:142-54.

14. Guerrero LA, Maas G, Hogland W. Solid waste management challenges for cities in developing countries. Waste Management. 2013 Jan; 33(1):220-32.

15. Simon AM. Analysis of activities of community based organizations involved in solid waste management, investigating modernized mixtures approach. The case of Kinondoni Municipality, Dar es Salaam, Tanzania. Wageningen University; 2008 May. p. 1-93.

16. Rahman M, Salequzzaman M, Bahar M, Uddin N, Islam A, Al Hrun AY . People's perception of the existing solid waste management of Khulna City Corporation (KCC) Area: A case study of participatory management. In the Proceedings of National Workshop for REGA and Clean Development Mechanism (CDM) Awareness and Motivation under the Asian Development Bank (ADB) Promotion of Renewable Energy and Energy Efficiency and Greenhouse Gas Abatement (PREGA) Project, Bangladesh Centre for Advanced Studies, Khulna. 2005; 6(3):1-8.
17. Bernstein J. Social assessment and public participation in MSWM. World bank, Urban Environment Thematic Group, Washington; 2004 Aug. p. 1-213.

18. Gibson K, Tierney JK .Electronic waste management and disposal issues and alternatives. Environmental Claims Journal. 2006 Dec; 18(4):321-32.

19. Mariwah S, Kendie SB, Dei AL. Residents perception of the solid waste management problem in the shama-ahanta-east metropolitan area, Ghana. Oguaa Journal of Social Sciences. 2010 Jan; 5(1):21-43.

20. Mgongolwa PG. Evaluation of a community based solid waste management project in Iringa municipality, Tanzania. Doctoral dissertation, Southern New Hampshire University; 2007 Dec.

21. Manyele SV, Anicetus $\mathrm{H}$, Bilia $\mathrm{MH}$.The Effect of globalization on Tanzanian. Review of Industrial and Medical Waste Practices in Dar es Salaam; 2003. p. 1-17.

22. Tchobanoglous G, Theisen H, Vigil S. Integrated solid waste management: engineering principles and management issues. McGraw-Hill; 1993 Jan. p. 978. 